Article

\title{
Sustainability Prerequisites and Practices in Textile and Apparel Supply Chains
}

\author{
Ronak Warasthe ${ }^{1,2, *}$, Finja Schulz ${ }^{1}$, Ralf Enneking ${ }^{1}$ and Marcus Brandenburg ${ }^{1,2(1)}$ \\ 1 School of Business, Flensburg University of Applied Sciences, 24943 Flensburg, Germany; \\ schulzfinja@gmx.de (F.S.); EnnekingRalf@web.de (R.E.); marcus.brandenburg@hs-flensburg.de (M.B.) \\ 2 Chair of Supply Chain Management, University of Kassel, 34127 Kassel, Germany \\ * Correspondence: ronakeh.warasthe@hs-flensburg.de
}

Received: 16 October 2020; Accepted: 26 November 2020; Published: 28 November 2020

\begin{abstract}
The proposed study deals with sustainable supply chain management (SSCM) in the textile and apparel (T\&A) industry. We analyze prerequisites and practices of supply chain (SC) sustainability in a multiple case study of the German and Ethiopian T\&A industry. Our analysis is based on ten semi-structured interviews conducted with the managers of seven companies in the Ethiopian T\&A production and the German fair fashion retail industries. The contribution of expert knowledge helps in identifying SC sustainability prerequisites and practices. The chosen cases of production in Ethiopia and retail in Germany highlight the complexity of T\&A SCs while representing both the suppliers' and retailers' perspectives, which is rare in the related literature. As a major research contribution, the study adapts a framework for SC sustainability in the chemical industry and transfers it to T\&A SCs. Moreover, practitioners from the T\&A industry find useful insights into relevant practices and their prerequisites, which helps in improving SC sustainability in this sector. The study reveals that management orientation and interest groups such as customers represent the most important prerequisites for sustainability. Manufacturers rely more on internal practices such as monitoring, while retailers focus on external sustainability practices, such as supplier development. In a comparative approach, similarities and differences between T\&A SCs and the chemical industry are identified.
\end{abstract}

Keywords: supply chain management; sustainable development; textile and apparel industry; ethiopia; germany; case study research

\section{Introduction}

Globalization has caused many geographical shifts in production sites towards emerging and developing countries. In the course of these shifts, structures of, and material flows within, respective Supply Chains (SCs) have been altered. Besides the ongoing pressure to reduce cost and lead time, the geographic complexity enhances the challenges faced by textile and apparel (T\&A) companies [1-3]. Particularly profitable to the T\&A industry, these shifts led a majority of production sites in this line of business to be moved to low-income countries.

Sustainability-related challenges arise in the context of often poor social and ecological standards within the production force, because sourcing in these regions has become a common practice in the T\&A industry. This is in contrast to the highly developed level of sustainable sourcing and operations achieved in industrialized regions and saturated markets [4-6]. Consequently, non-governmental organizations (NGOs) and the media put public pressure on focal firms in T\&A SCs to review and adapt sustainability practices throughout the whole supply network $[7,8]$. Sustainability practices affect all stages of the $\mathrm{SC}$, as focal firms propagate this pressure and pass on environmental and social sustainability requirements upstream in the SC to their suppliers and sub-suppliers $[9,10]$. 
The conventional T\&A SC, as presented in this paper, is widely and publicly criticized for its excessive use of toxins and the critical labor conditions of its workforce. As such, apparel companies pursue the implementation of sustainability measures, such as decreasing emissions and advancing the working conditions of their production employees [11,12]. This leads to the question of which prerequisites and practices of SC sustainability are relevant in T\&A SCs.

To answer this question, this paper outlines different practitioners' perspectives on the sustainable development of the T\&A industry, and gives insights into the characteristics and structures of different SC tiers. Expert interviews are conducted in the two most unequally developed regions, namely Ethiopia and Germany. The findings of the conducted study contribute to the scientific research on sustainability in T\&A SCs. Practitioners find insights into challenges and opportunities for sustainability in apparel SCs.

The remainder of this paper is structured as follows. The next section gives insights into the relevant concepts and theoretical background of this study. The third section describes the research method of the case study, including the coding scheme. The fourth section highlights the findings of the expert interviews as well as qualitative data analyses, and outlines distinctive features and similarities with regards to sustainability prerequisites and practices. The results are discussed and research contributions and managerial implications are outlined in the fifth section. Concluding remarks on the limitations of the study and on future research perspectives are given in the last section.

\section{Background}

Sustainable supply chain management (SSCM) is defined as the "management of material, information and capital flows as well as cooperation among companies along the SC while integrating goals from all three dimensions of sustainable development, i.e., economic, environmental and social, which are derived from customer and stakeholder requirements" [10] (p. 1700). SSCM prerequisites and practices are based on the triple bottom line (TBL) approach, which comprises the economic, the environmental and the social dimensions of sustainability [13]. SC decisions on strategic network configuration and design, as well as on the execution and control of operational processes, affect sustainability performance and the related risks [14].

Brömer et al. (2019) [15] analyze the prerequisites and practices of SC sustainability in the chemical industry, and propose a related framework, depicted in Figure 1. Interviews with managers from chemical firms reveal the prerequisites, which are grouped by SC configuration and orientation and practices are categorized as external and internal ones. Since the study at hand builds upon this framework, these constructs are briefly introduced in the following.

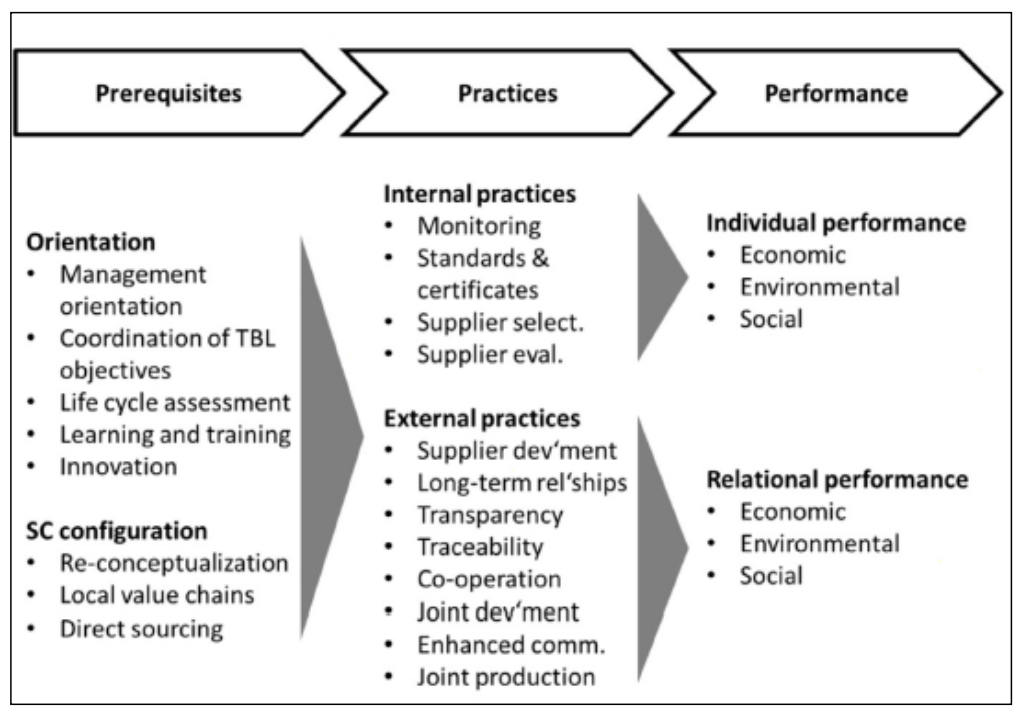

Figure 1. Sustainable supply chain management framework linking sustainability practices, prerequisites, and performance impacts [15]. 
Two organizational attributes, namely management orientation and the ability to be innovative, represent important prerequisites for SC sustainability [16]. A proactive and committed management is necessary to integrate SSCM practices into an organization in the short-, mid- and long-term [16]. Societal demands for higher social and environmental standards should be integrated into the corporate strategy [17]. A sustainable SC involves the inclusion of non-governmental organizations (NGOs) and community members, and even competitors that have played no role or were treated as disrupting factors in a traditional SCM [18]. Re-conceptualizing the SC with the involvement of non-traditional members and the consideration of the impact of corporate decisions on these stakeholders can provide expertise on the potential risks and add legitimacy, and thus represents a key factor for SSCM [16]. The learning and training of staff members is also key to sustainable development, because it needs to reflect the corporate strategy and adapt to the evolving requirements and practices that follow a management reorientation towards sustainability $[19,20]$.

Sustainability practices, including corporate strategy, organization culture and transparency, are decisive factors of SSCM [21]. Kot et al. (2020) identified the mediating role of strategic SCM on socio-environmental SC sustainability [22]. Several studies point out the necessity of coordination and collaboration for risk management in complex apparel SCs. The scientific literature mainly focuses on case studies or particular challenges, and suggests integrating sustainability into core business practices and increasing SC transparency to drive change in the apparel industry [23].

The T\&A SC faces challenges in all three TBL dimensions, because a majority of its production sites are located in emerging economies and developing countries [2,3]. Especially in the T\&A industry, cost pressure (economic dimension) is often in conflict with environmental and social challenges, such as violations of labor standards, the high consumption of resources (e.g., energy, water or chemicals) or dyeing processes that pollute groundwater [24-26]. The T\&A production considerably affects the energy intensity of Asian textile manufacturing countries [27]. Sustainability in the T\&A industry has recently gained increasing attention [28]. The impacts of non-economic sustainability factors are particularly important, especially because the apparel industry accounts for around $9 \%$ of the world's workforce, $4 \%$ of worldwide exports and $2 \%$ of the global GDP [29]. As a consequence, stakeholders force fashion brands to implement sustainability measures and to propagate sustainability across the global multi-tier supply networks.

As illustrated in Figure 2, the first process steps within these T\&A supply networks correspond with textile production, and include the materials used (natural/synthetic fibers) as well as yarn and fabric production. While about half of the produced textiles are further processed into apparel goods [30,31], the other half will be used as household items (i.e., carpets, furnishing) and industrial goods (i.e., belting, upholstery in car industry).

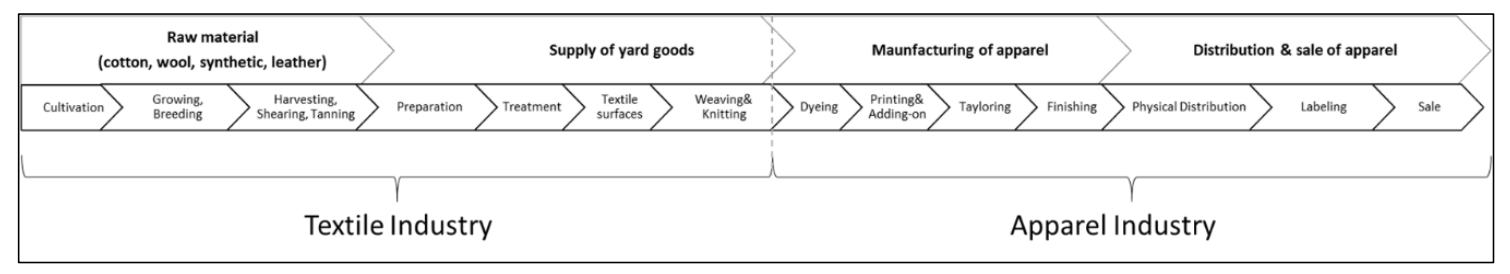

Figure 2. Process steps of the textile and apparel industry (based on Warasthe and Brandenburg, 2018).

Freise and Seuring (2015) [32] conceptualize the internal and external environmental and social sustainability-related drivers and measures in European apparel SCs, and suggest studying emerging economies, where most of the manufacturers are located, and then comparing the different markets. Despite current the developments of African countries like Ethiopia being added to the map of T\&A SCs, research with a focus on Africa in T\&A SCs is scarce. Ethiopia's economy is primarily based on agriculture, but since 2010 it has developed into an industrial economy, with the government's priority set on strategic sectors such as light manufacturing, including T\&A manufacturing [33,34]. 
Considering its significant potential in the global market, the T\&A industry was put into a central position to further advance the country's evolving process [35].

For summaries of the SSCM literature with a focus on the T\&A industry, we refer to earlier systematic literature reviews. With a focus on corporate social responsibility (CSR) and overall social sustainability, Kökzal et al. (2017) [25] found only a few studies on sustainability reporting and labeling in the T\&A industry, and proposed the integration of socially related practices with sustainability risk and performance in T\&A SCs. Mukendi [36] et al. (2020) highlighted the managerial orientation towards sustainability while further exploring future organizational and consumer habits. In their literature review on CSR in the luxury sector, Kunz et al. (2020) [37] assumed that luxury products serve as models in the industry, and identified the lack of internal communication of sustainability measures and fair-trade labels as an under-researched area.

Yang et al. (2017) [38] pointed at the lack of research on sustainable retailing in the T\&A industry. They identified sustainable and second-hand fashion retailing, green branding and eco-labeling, as well as reverse logistics in fashion retailing and emerging retailing opportunities in e-commerce, as promising areas for future research.

Two studies analyze the related literature regarding the sustainable development of T\&A SCs by particular means. Garcia-Torres et al. (2019) [39] focused on the traceability of sustainability and conceptually framed (S)SCM based on their findings, and the other study presents the potential of local manufacturing to further develop TBL sustainability (Sirilertsuwan, et al., 2018) [40]. The study conducted by Karaosman et al. (2016) [41] categorized sustainability practices with a focus on product, process and SC levels, and created a classification framework. In their study on circular economies, Jia et al. (2020) [42] identified general sustainability practices such as leadership commitment and long-term relationships with suppliers, but in contrast to the study at hand, clearly focused on practices that particularly apply to circular economy, such as measures related to the collecting and recycling of apparel.

\section{Research Method and Scientific Rigor}

Given the high relevance of sustainability in the T\&A industry, the manufacturing and retail stages in this sector are well-suited fields for empirical investigations into SSCM. The geographical spread of T\&A SCs allows for taking different views on sustainability from the perspectives of fashion retailers in developed markets and T\&A firms in emerging economies, respectively. As such, we study T\&A manufacturing in Ethiopia and fair fashion retail in Germany in a multiple case study.

We use a qualitative research approach to get insight into the managerial perception of sustainability, show best practices, and thus examine the reciprocity of organizational factors within the T\&A industry that encourage the implementation of sustainability measures along the SC. In this study, we follow the five steps of case research introduced by Stuart et al. (2002) [43], which are shown in Figure 3 and described in greater detail in the remainder of this section.

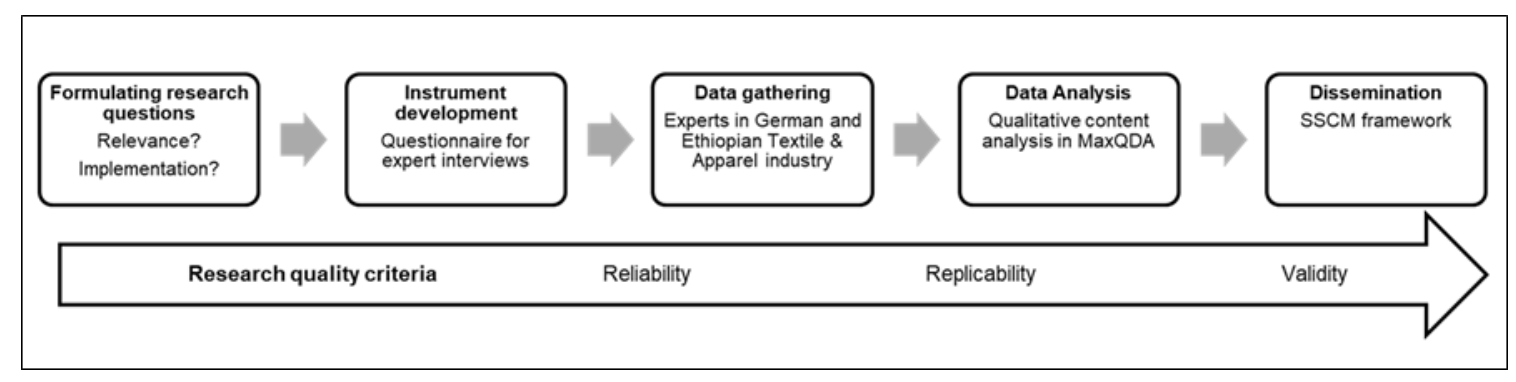

Figure 3. Five steps of case-based research (based on Stuart et al., 2002). 


\subsection{Formulating the Research Question}

In order to determine the requirements and conditions that lead to SC transformation towards sustainability through the example of the German and Ethiopian T\&A industries, the study at hand aims to answer the following research question:

"What prerequisites and practices drive and enable sustainability in TEA SCs?"

On a more detailed level, the study highlights the relevance of management orientation and the challenges and benefits of the implementation of sustainability measures.

\subsection{Instrument Development}

For comparability reasons and to address the same topics with all interviewees, we conducted semi-structured interviews based on a questionnaire (see Appendix A). This approach simultaneously gives clear guidance and allows us to flexibly react on new matters or particular aspects that emerge during the interview [43-45]. The questionnaire covers the following seven topics that reflect the constructs framed by Brömer et al. (2019) [15], and information on the interviewees and the respective company:

(a) Managerial orientation toward sustainability;

(b) Depiction of the value chain and its shareholders;

(c) Sustainability rules and regulations within the company;

(d) Procurement/purchasing and product design;

(e) Sustainability standards and certificates;

(f) Cooperation, communication, coordination and supplier relationship in supply networks;

(g) Sustainability practices.

\subsection{Data Gathering}

As depicted in Table 1, ten managers, five each from Ethiopian manufacturers and German retailers, from in total seven companies, were interviewed between Q4/2019 and Q1/2020 to get access to in-depth expertise on SSCM in the T\&A industry. The Ethiopian manufacturers were recommended through contacts at local universities, while the German retailers were chosen via an online search for companies with a dedicated standpoint regarding sustainability. The number of experts interviewed per company varies within the sample, and the total number of conducted interviews is in line with earlier operations management studies that range from three to eleven considered cases [16]. The interviews, each lasting between 60 and $120 \mathrm{~min}$, were conducted face-to-face in the English language in Ethiopia, while the German retailers were interviewed in the German language by phone. The interviews were recorded and transcribed following transcription rules in accordance with Kuckartz (2007) [46]. To ensure confidentiality, personal and corporate data was anonymized.

\subsection{Data Analysis}

The transcribed interviews were evaluated by qualitative content analysis relating to Mayring (2014) [47]. In line with the deductive approach, the structural dimensions and analytical categories were derived from the conceptual framework proposed by Brömer et al. (2019) [15]. They were complemented by inductively developed categories (geographical position, alliances and interest groups) that were derived from the interview data in an iterative process [48]. The transcripts were divided, first into smaller segments and then into analytical units, and then encoded with MaxQDA, a qualitative data analysis software. Thus, each analytical unit was described by a specific category that summarizes or describes its significant characteristics. 
Table 1. Conducted expert interviews.

\begin{tabular}{|c|c|c|c|c|c|}
\hline Interview No. & Interviewee & Position & Company & Position & Country \\
\hline 1 & A.1 & Founder and owner & A & Fair fashion brand & \multirow{5}{*}{ Germany } \\
\hline 2 & B.1 & Marketing manager & B & $\begin{array}{l}\text { Fair organic } \\
\text { fashion brand }\end{array}$ & \\
\hline 3 & C.1 & Co-owner & $\mathrm{C}$ & $\begin{array}{l}\text { Fair organic } \\
\text { fashion brand }\end{array}$ & \\
\hline 4 & D.1 & Managing director & $\mathrm{D}$ & $\begin{array}{l}\text { Sustainable work } \\
\text { clothing brand }\end{array}$ & \\
\hline 5 & E.1 & Founder and owner & $\mathrm{E}$ & Fair fashion brand & \\
\hline 6 & F.1 & General manager (GM) & $\mathrm{F}$ & T\&A manufacturer & \multirow{5}{*}{ Ethiopia } \\
\hline 7 & G.1 & Assistant GM-Merchandising & \multirow{4}{*}{ G } & \multirow{4}{*}{$\begin{array}{c}\text { Apparel } \\
\text { manufacturer }\end{array}$} & \\
\hline 8 & G.2 & Assistant GM-Plant logistics & & & \\
\hline 9 & G.3 & Assistant GM-Compliance Mgr & & & \\
\hline 10 & G.4 & $\begin{array}{l}\text { Assistant GM-Head of Human } \\
\text { Resource Management (HR) }\end{array}$ & & & \\
\hline
\end{tabular}

\subsection{Dissemination}

To disseminate the findings, the relevant constructs of the prerequisites and practices of SC sustainability in the T\&A industry were framed and compared to the ones in the chemical industry as detected by Brömer et al. (2019) [15]. Thereby, the drawn conclusions were relevant on a more general level that goes well beyond the chosen geographical scope of the study and the considered industry sector.

\subsection{Scientific Rigor}

Scientific rigor was ensured throughout the study. Reliability and replicability were achieved by thorough and continuous documentation of the interviews, clear transcription rules, a standardized questionnaire for the interviews, as well as by audio recordings [43-45]. Construct validity was accomplished by the use of an existing framework. The multi-case study method ensures that several sources of evidence are available. A systematic investigation scheme was developed, similar to a case study protocol. Combined with interviews of a multitude of experts from different companies, this will support external validity. The questionnaire was pre-tested in order to assure internal validity [44].

\section{Results}

This section of the study presents the results of the qualitative analysis, grouped into sustainability prerequisites as well as internal and external practices.

\subsection{Prerequisites of SC Sustainability in the TEA Industry}

The results listed in Table 2 illustrate that prerequisites in general are less often addressed by the German retailers. This is caused by the fact that the German retailers were all founded with the intrinsic motivation of offering fair or organic apparel. As such, they work less strongly towards implementing sustainability as a first step, but rather focus on being further ahead of the conventional retailers regarding sustainability. While the overall amount of coding of the prerequisite categories differs, the proportionate coding of both regions shows similarities. 
Table 2. Coding of "Prerequisites" categories.

\begin{tabular}{llll}
\hline Analytic Category & GER Retailers & ETH Manufacturers & Total \\
\hline Management orientation & $29(28 \%)$ & $75(38 \%)$ & $104(34 \%)$ \\
Interest groups & $20(19 \%)$ & $50(25 \%)$ & $70(23 \%)$ \\
Geographical position & $16(15 \%)$ & $26(13 \%)$ & $42(14 \%)$ \\
Alliances & $16(15 \%)$ & $22(11 \%)$ & $38(13 \%)$ \\
Learning and training & $5(5 \%)$ & $18(9 \%)$ & $23(8 \%)$ \\
Re-conceptualization & $11(11 \%)$ & $2(1 \%)$ & $13(4 \%)$ \\
Local value chains & $6(6 \%)$ & $3(2 \%)$ & $9(3 \%)$ \\
Innovation & $1(1 \%)$ & $4(2 \%)$ & $5(2 \%)$ \\
Total & $\underline{\mathbf{1 0 4}(\mathbf{1 0 0} \%)}$ & $\mathbf{2 0 0 ( 1 0 0 \% )}$ & $\mathbf{3 0 4 ( 1 0 0 \% )}$ \\
$n=$ Interviews & 5 & 5 & 10 \\
\hline
\end{tabular}

Management orientation is considered the most important prerequisite for sustainability by all interviewees, pointing out the corporate strategy (Company A, B, C, D, E) as well as the annual sustainability report as a corporate guideline (all members of Company $\mathrm{G}$ ).

"[... ] we are the only group [... ] who publishes this sort of papers each and every year. But there is no pressure from any authorities to publish such report, but we are doing it. Because we know how important these things are to us. So, particularly for Company $G$ this is very important. We do have a certain particular department [ ... ] with - I think-more than two hundred persons over there who are only working regarding sustainability." (G1)

Interest groups, in particular customers, are considered strong drivers for sustainability measures by both interviewed groups. For the retailers, their rather demanding fair fashion customers are drivers of sustainable development.

"[ ... ] the consumer holds a ballot card with every sales slip in their hand. [ . . ] because I believe one has an incredible market force. With every purchase they declare "that's what I want ". And for every piece you buy a new one gets manufactured. That's where the consumer has an incredible power position." (C1)

For retailers, the geographical position of their suppliers can pose as a prerequisite for both social and ecological sustainability.

"The first criterium for my sustainability strategy is the proximity to my production location.

This means short distances are crucial. Then I look at the working conditions of the supplier. We work with an Austrian supplier for example." (A1)

The manufacturers in Ethiopia experience a disadvantage regarding their geographical position, considering that Ethiopia is landlocked and has a challenging infrastructure, particularly since Company F sources its fabrics from South Asia, which is a challenge to environmental sustainability.

"[ ... ] suppose something is coming from Egypt, or China it will take up to 21 days to the port in Djibouti. Djibouti is not in Ethiopia." (F1)

The Ethiopian manufacturers express both pressure and support regarding sustainable development from their customers, as well as NGOs. Customers (i.e., retail buyers) often require sustainability standards and certifications from suppliers, but also offer support in obtaining them. For the Ethiopian firms, NGOs may act as stakeholders (interest group) and as alliance partners, which is indicated by the frequent occurrence of the alliance coding. Governmental organizations also serve as alliance partners to Ethiopian T\&A firms. 
"Yes, some customers, they push too much. Sometimes they also take the commitment to help in the certification process [...] directly or indirectly. [ ... ] Some of them, they even go to the extent that $[. .$.$] can support on the fee, certification fee or something. There are also some partners like$ GIZ (Deutsche Gesellschaft für internationale Zusammenarbeit, German organization for global collaboration) who also motivate us, support us to be a worldwide competitor [ ... ]." (F1)

Some of the interviewed German retailers are members of fair/organic fashion networks that establish partnerships for the exchange of sustainability competences (Companies D\&E).

Learning and training is crucial for Ethiopian T\&A manufacturers, while this is less important to German retailers. In the comparably young Ethiopian T\&A industry, skilled laborers and managers are sought-after, and training this staff towards a sustainable conscience is a prerequisite for SSCM.

"To add something, for our sustainability our workforce, there are training centres here." (G2)

"[ ... ] so, we have to develop them. And that's why we feel always like the training is more important. Because we have to train them about their legal rights, safety standards, securities, and at the same time productivity. At the same time, their role in responsibility and how they can add their value in this. How they can add their contributions in the total company. The several trainings are more important." (G3)

The interviews show that local value chains and innovation are hardly relevant as prerequisites of SC sustainability in the T\&A industry.

\subsection{Internal Sustainability Practices in TEA SCS}

Table 3 shows the coding of the internal sustainability practices as addressed by Ethiopian T\&A manufacturers and German retailers.

Table 3. Coding of "Internal Practices" categories.

\begin{tabular}{llll}
\hline Analytic Category & GER Retailers & ETH Manufacturers & Total \\
\hline Standards and & $20(56 \%)$ & $18(42 \%)$ & $38(48 \%)$ \\
Certifications & $5(14 \%)$ & $14(33 \%)$ & $19(24 \%)$ \\
Monitoring & $7(19 \%)$ & $6(14 \%))$ & $13(16 \%)$ \\
Supplier Selection & $4(11 \%)$ & $5(11 \%)$ & $9(12 \%)$ \\
Supplier Evaluation & $\mathbf{3 6 ( 1 0 0 \% )}$ & $\mathbf{4 3}(\mathbf{1 0 0} \%)$ & $\mathbf{7 9 ( 1 0 0 \% )}$ \\
Total & 5 & 5 & 10 \\
$n=$ Interviews & & & \\
\hline
\end{tabular}

German retailers as well as Ethiopian manufacturers consider standards and certifications as crucial for SC sustainability. Both manufacturers and retailers rely on standards and certifications rather than on conducting their own supplier evaluations. Ethiopian interviewees report that their companies continuously audit to ensure that the sustainability requirements of retail buyers and the sustainability demands of certification schemes are met.

"Sometimes we audit ourselves and sometimes the customers send their transparency auditors. [ ... ] They do have their own audit team." (G1)

"Already we are WRAP (Worldwide Responsible Accredited Production certificate in sewn-product sector) certified and BSCI (Business Social Compliance Initiative, system that helps companies to gradually improve working conditions in their supply chain) certified. First of all, WRAP and BSCI we are maintaining and buyer requirements we are maintaining." (G3)

For the retailers, standards and certificates are considered a substitute for supplier evaluation, and also serve as a tool to communicate unique selling propositions to customers [49]. However, certificates are also seen critically, as they are costly. 
"And yes, many customers like to see a certificate and think certificates are great but hardly anyone questions the values the certificate represents." (E1)

I believe it is important to be able to feature certificates, that you can say [... ] customer can buy it with a clean conscience." (C1)

"For cotton we have a very strict guideline. If it is a pure cotton product it has to be GOTS (Global Organic Textile Standard) certified, otherwise it won't be sold in our store. [ ... ] we are quite consequent about that." (C1)

"The certification organisations [... ] I have previously mentioned, supervise the social and environmental conditions of production." (B1)

Ethiopian manufacturers focus on self-monitoring to meet the sustainability requirements of their customers. Supplier selection and evaluation play subordinate roles for Ethiopian T\&A manufacturers, while supplier selection is more important for the German retailers than monitoring. Company F, a manufacturer, produces its own yard goods and most of its suppliers are already nominated, and thus pre-evaluated by its customers, i.e., by retailers.

"[ ... ] we do not select suppliers. Sometimes we need to source from outside. That is nominated by the customers." (G1)

"There are also cases where we deal with what you call nominated suppliers. These are customer nominated suppliers." (F1)

"At the beginning of the business we just want to know: Have you nominated your own supplier or can we propose you the same thing. [ ... ] or other customers have approved it, definitively they have audited the project. They have checked every single inch of the project, then they have approved it. So, we just buy from them." (G1)

\subsection{External Sustainability Practices in TEA SCS}

The coding of external practices in the interviews is listed in Table 4 . The German retailers address external practices ( 43 codings, see Table 4 ) more often than internal ones ( 36 , see Table 3 ). This can be explained by the circumstance that retailers receive sustainability requirements from consumers and propagate them to their upstream SC partners. Manufacturers have to comply with these requirements, which explains why Ethiopian manufacturers prefer internal sustainability practices (43 codings, see Table 3 ) over external ones ( 23 codings, see Table 4 ).

Table 4. Coding of "External Practices" categories.

\begin{tabular}{llll}
\hline Analytic Category & GER Retailers & ETH Manufacturers & Total \\
\hline Transparency & $10(23 \%)$ & $5(22 \%)$ & $15(23 \%)$ \\
Traceability & $6(14 \%)$ & $6(26 \%)$ & $12(18 \%)$ \\
Long-term rel'ships & $9(21 \%)$ & $3(13 \%)$ & $12(18 \%)$ \\
Supplier dev'ment & $11(26 \%)$ & $0(0 \%)$ & $11(17 \%)$ \\
Co-operation & $1(2 \%)$ & $5(22 \%)$ & $6(9 \%)$ \\
Enhanced communic. & $3(7 \%)$ & $3(13 \%)$ & $6(9 \%)$ \\
Joint development & $3(7 \%)$ & $1(4 \%)$ & $4(6 \%)$ \\
Total & $\mathbf{4 3 ( 1 0 0 \% )}$ & $\mathbf{2 3}(\mathbf{1 0 0} \%)$ & $\mathbf{6 6}(\mathbf{1 0 0} \%)$ \\
$n=$ Interviews & 5 & 5 & 10 \\
\hline
\end{tabular}

Transparency as a sustainability practice serves for both the Ethiopian retailers as well as the German retailers as a tool to gain their respective customers' trust, and is thus seen as a vital part of the buyer-supplier relationship. In addition, the retailers use it to communicate a vitreous sustainable SC to their customers. Transparency gives evidence of the SC sustainability of all firms in the supply network. 
"So, we have to be transparent. It is very important to get their [customers'] confidence and getting their assistance. So, it is very important." (G4)

"That's a main requirement because first of all, a buyer's requirement is transparency." (G3)

"We pick sustainably produced goods on a daily basis and communicate this through our social media accounts and our newsletter but also on the shop floor daily. We try to get it as close as possible to our customer." (C1)

The Ethiopian manufacturers as well as the German retailers consider traceability as the most important external sustainability practice. Traceability measures serve manufacturers as a tool to achieve certification schemes and to comply with customer requirements. Moreover, they help retailers in retracing and obtaining their requirements from their suppliers. Ideally, it enables tracking and tracing sustainability performance across the whole supply network.

"[... ] there are customers that strongly, consistently require to barcode all the products. [ ... ] to use RFID labels. And [... ] the transmission from that label could detect which item is where and where it is produced or which item-number it is." (F1)

"So that most of all us, as entrepreneurs have the overview. Where are our products coming from, how are they produced, and under which circumstances? We do that [ ... ] by means of certifications. "(D1)

Long-term relationships ensure economic sustainability and, thus, are often considered by retailers and manufacturers.

"[ ... ] in terms of cost saving. Also, in terms of trust and relationships. You know nowadays business has turned to be [... ] just transactional; it is about relationships." (F1)

"This is not something you achieve from one season to the next but it is an opportunity and really depends on long-term relationships, long-term supplier commitment and not just chasing the lowest price." (A1)

For German retailers, supplier development goes hand-in-hand with long-term relationships and enhanced communication. When applying supplier development as a sustainability practice, the retailers build on the willingness of their suppliers to develop sustainability measures along with the customers.

"[ ... ] but we have the trust now and we know some of the producers for more than ten years and we sense, we're on the same page regarding our mindset and actions." (B1)

The Ethiopian manufacturers, as already examined for the internal practices, rely rather seldomly on suppliers, and if they do so, these suppliers are in most cases already nominated by the retail customers. The manufacturers, unlike the German retailers, consider cooperation to further environmental and social sustainability factors to be more important. This observation is surprising, because cooperation can only be successful if both partners see the importance and are willing to collaborate.

"[ ... ] we are always trying to change with our third buyer or customer perspective. This is our motor [for] sustainability. If we are not running with them [ ... ] then, we cannot give them, work with them. We cannot keep them. In fact, the buyers will change us. So, for sustainability we can always care." (G2)

Both groups, Ethiopian manufacturers and German retailers, see enhanced communication as a building block for fruitful relationships and cooperation. However, compared to other external practices, the relevance of enhanced communication is limited.

"My opinion is first of all, dialogue. Sitting together and work together." (G3)

Joint development plays a minor role among the external sustainability practices in T\&A SCs, and joint production, a relevant sustainability practice for chemical manufacturers (Brömer et al., 2019) [15], is not addressed by any of the interviewees from the T\&A firms. 


\subsection{Framing the Constructs}

To frame the prerequisites and practices of sustainability in T\&A SCs, we adapt a framework designed by Brömer et al. (2019) [15] and illustrated in Section 2. The resulting framework depicted in Figure 4 helps in answering the research question, "what prerequisites and practices drive and enable sustainability in T\&A SCs?".

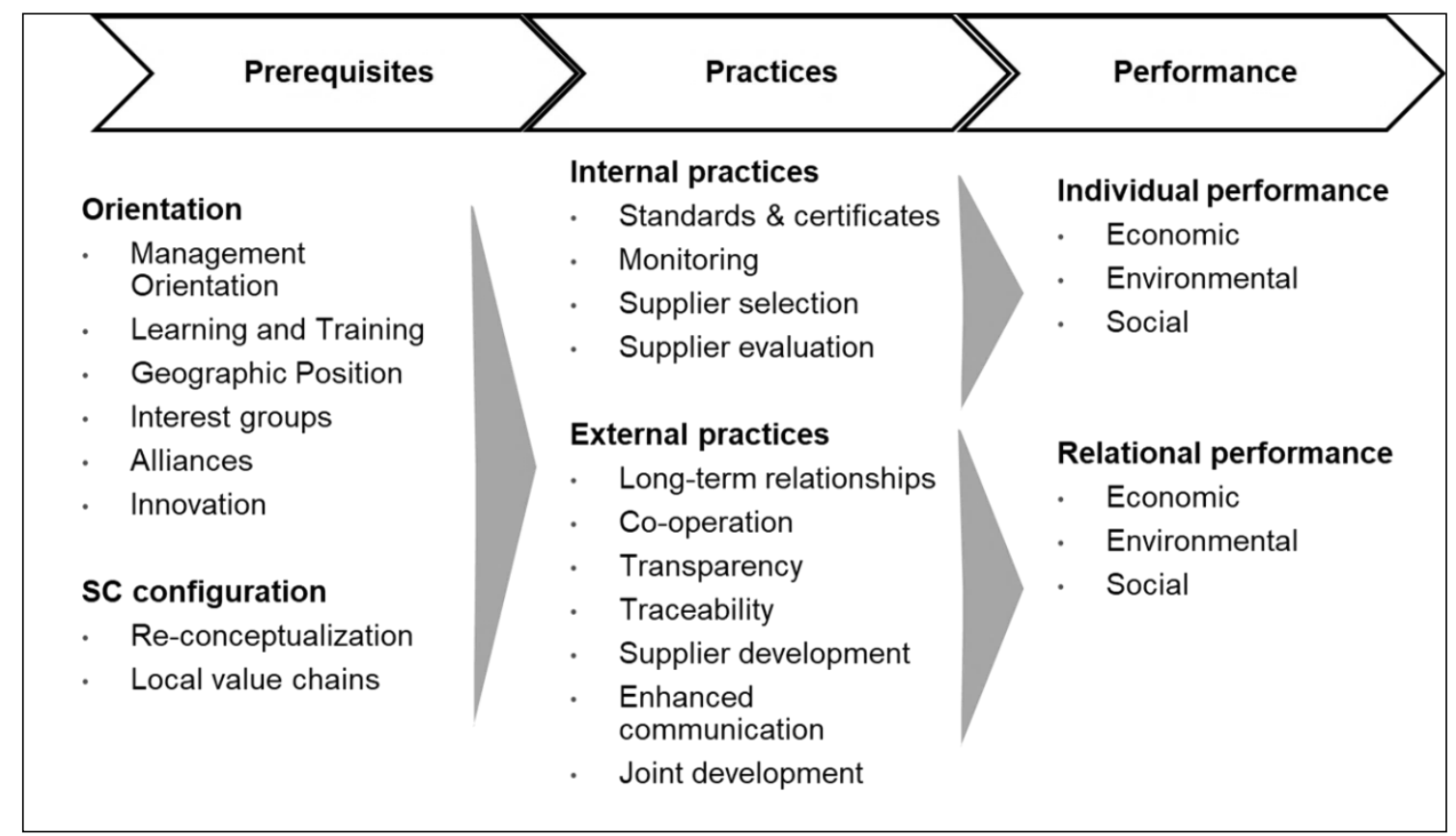

Figure 4. SSCM framework for the T\&A industry (based on Brömer et al., 2019).

A comparison of results between our study and Brömer et al.'s (2019) [15] as listed in Table 5 shows similarities and differences between T\&A SCs and the chemicals industry.

Table 5. Similarities and differences between T\&A SCs and the chemicals industry.

\begin{tabular}{|c|c|c|}
\hline Sector & Prerequisites & Practices \\
\hline T\&A only & $\begin{array}{ll}- & \text { Geographic position } \\
\text { - } & \text { Interest groups } \\
\text { - } & \text { Alliances } \\
\end{array}$ & $\mathrm{n} / \mathrm{a}$ \\
\hline Both sectors & $\begin{array}{ll}\text { - } & \text { Management orientation } \\
\text { - } & \text { Learning and training } \\
\text { - } & \text { Innovation } \\
\text { - } & \text { Re-conceptualization } \\
\text { - } & \text { Local value chains }\end{array}$ & $\begin{array}{ll}\text { - } & \text { Monitoring } \\
\text { - } & \text { Standards and certificates } \\
\text { - } & \text { Supplier selection } \\
\text { - } & \text { Supplier evaluation } \\
\text { - } & \text { Supplier development } \\
\text { - } & \text { Long-term rel'ships } \\
\text { - } & \text { Transparency } \\
\text { - } & \text { Traceability } \\
\text { - } & \text { Co-operation } \\
\text { - } & \text { Joint dev'ment } \\
\text { - } & \text { Enhanced communic. } \\
\end{array}$ \\
\hline Chemicals only & $\begin{array}{ll}\text { - } & \text { Coordination of TBL objectives } \\
\text { - } & \text { Life cycle assessment } \\
\text { - } & \text { Direct sourcing }\end{array}$ & - Joint production \\
\hline
\end{tabular}


The results on the sustainability prerequisites for T\&A SCs indicate large similarities with the chemical industry. The importance of management orientation and local value chains, as well as innovation and learning and training, is addressed in both sectors. In addition, the re-conceptualization is important to chemical firms as well as to German apparel retailers. The geographical position and alliances with interest groups are more relevant in global, multi-tier T\&A SCs than in the chemical firms. In contrast to the chemical industry, life cycle assessment and the coordination of TBL objectives, as well as direct sourcing, are not addressed by managers from the T\&A firms in our study. To a certain extent, this is surprising, because life cycle assessment would help in improving the sustainability of fast fashion, and conflicts between TBL objectives exist and need to be resolved in nearly any industry.

All sustainability practices mentioned by T\&A managers are also important to the chemicals industry, and joint production is the only practice from the chemicals sector that is not addressed by managers from T\&A SCs. Most likely, transferring the concept of joint production from chemicals manufacturing to T\&A production is hardly possible due to technical differences between both sectors.

The results of the comparison illustrate that a large majority of sustainability prerequisites and practices are important to and applicable in both sectors. However, the emphasis within the categories varies between both industries due to the particularities of global T\&A SCs and their stakeholders, and due to differences between manufacturing technologies in these two sectors.

\section{Discussion}

The study at hand has empirically investigated and confirmed the requirements, means and interrelations that advance sustainability in T\&A, which were identified through expert interviews and a subsequent qualitative content analysis. An SSCM framework on sustainability prerequisites and practices for the chemical industry developed by Brömer et al. (2019) [15] has been reframed for T\&A SCs based on the interview results. The study has given particular insight into manufacturers in the Ethiopian T\&A industry and German fair/organic fashion retailers. It has highlighted the complexity of global, multi-tier T\&A SCs from both the suppliers' and the retailers' perspectives.

\subsection{Summarized Findings}

We find that the fashion retailer cases proactively apply sustainability measures out of an intrinsic motivation, since they have been founded and operate as fair/organic fashion retailers. This is in contrast to the modus operandi of the conventional T\&A manufacturers, which tend to react on the sustainability requirements of customer markets and other stakeholders. While certifications pose as decision support tools for retailers, and as figureheads for their customers, they are considered costly customer requirements for manufacturers. The differences in the results for sustainability prerequisites and practices between Ethiopian and German interviewees arise from their SC positions (retailers vs. manufacturers) and their business models (fair fashion vs. conventional production), and less from their geographical particularities and distance. Low labor costs and government incentives promising high profitability lead to one of the most recent developments in T\&A SCs, which is the shift of production from established producers in South and South-East Asia to Eastern African countries [34,50].

\subsection{Research Contribution}

This paper contributes to the research on sustainability in T\&A SCs. A framework for SC sustainability in the chemical industry designed by Brömer et al. (2019) [15] is adapted and transferred to T\&A SCs through cases of Ethiopian manufacturers and German retailers. Our study elaborates on T\&A manufacturers and retailers and, hence, helps in filling the gap in SSCM research on T\&A retailers, as detected by Yang et al. (2017). Such a representation of both the suppliers' and the retailers' perspectives is rare in the related literature.

The prerequisites and practices of sustainability in the T\&A industry as presented in this study complement sustainability enablers and barriers in T\&A SCs, as identified by Oelze (2017) [51] and Raut et al. (2017) [52]. In line with Pagell and Wu (2009) [16], our case study exemplifies for the 
T\&A industry that the implementation and execution of sustainability practices leads to a potential improvement in the TBL performance. All interviewees in our cases see management orientation as an important prerequisite of sustainability in T\&A SCs, which confirms insights gained by Beske and Seuring (2014) [20] and Jia et al. (2020) [42]. Our study validates the relevance of standards and certificates, as well as transparency, in sustainability, as detected by Oelze et al. (2020) [49] and Kumar et al. (2017) [5], respectively. We identify enhanced communication as an important SSCM practice in the T\&A industry and, thus, emphasize that deficits in the communication and transparency of sustainability measures, as detected by Kunz et al. (2020) [37] and Garcia-Torres et al. (2019) [39], need to be resolved. The adapted framework illustrates that customers and other interest groups trigger sustainability in the T\&A industry. This particularity mirrors the findings of earlier studies that identify interest groups and stakeholders as sustainability drivers in the T\&A industry $[51,53,54]$. In line with Kökzal et al. (2017) [25], we recommend developing the conceptual framework further so as to integrate SSCM prerequisites and practices with risk and performance.

The German and Ethiopian cases presented in this paper complement the comparably small set of studied T\&A SCs in Africa. Our study confirms the high relevance of sustainability for T\&A manufacturing in Ethiopia, as emphasized by Khurana (2018) [35].

\subsection{Managerial Implications}

The increasing importance of SSCM strengthens the practical relevance of the study at hand. SC sustainability implementations may help firms gain a competitive advantage that is crucial for the innovation and business success of Ethiopian T\&A companies [55,56]. Long-term relationships further drive the sustainable development of the Ethiopian T\&A sector, which is an important factor for the economy in that country, just as in the leather industry [57].

The managerial implications of our study guide practitioners towards the implementation of SC sustainability in the T\&A industry. Management incorporating the ideas of sustainability, the learning and training of staff members, and an effective communication within the company and SC is key to success when rolling out sustainability initiatives and measures. These insights complement the findings of Prasad et al. (2017) [58], who recommend Base of Pyramid producers to form cooperatives, to engage in political unionization, and to ensure that their social networks expand beyond local communities.

\section{Conclusions}

The study at hand has empirically investigated and confirmed the requirements, means and interrelations that advance sustainability in T\&A, which were identified through expert interviews and a subsequent qualitative content analysis. An SSCM framework on sustainability prerequisites and practices for the chemical industry developed by Brömer et al. (2019) [15] has been reframed for T\&A SCs based on the interview results. The study has given particular insight into manufacturers in the Ethiopian T\&A industry and German fair/organic fashion retailers. It has highlighted the complexity of global, multi-tier T\&A SCs from both the suppliers' and the retailers' perspectives.

Limitations arise from the comparably low number of interviews as well as from the geographical scope of the study, and its particular focus on the prerequisites and practices of SC sustainability. Broadening the perspective of traditional markets and industrialized economies with growth markets is one potential direction for sustainable T\&A SCs. In general, studying the sustainability-related impacts of global sourcing, particularly from emerging economies, represents a promising area for future research.

Though research into SSCM practices, performances and risks in the T\&A industry advances, different aspects are not fully elaborated and, thus, merit being studied further. Research opportunities, such as the analysis of risk and performance categories, can be derived from the results of the study at hand. We encourage conducting conceptual and empirical research by qualitative and quantitative studies. Further case studies or broad surveys in the related field may empirically substantiate theoretical insights. Moreover, quantifying the performance and risk impacts of sustainability-related 
prerequisites and practices helps in managing, further developing, and thus improving, SC sustainability in general, and in the T\&A industry in particular.

Author Contributions: The study represents joint work of all four authors. M.B and R.W. designed the research study. R.W. together with F.S. and R.E. conducted and analyzed the interviews. R.W. also mainly contributed to the writing of the manuscript. M.B. supported the writing of the manuscript and particularly added the conceptual framework and the conclusions section. Editing of the draft versions and reworking of the final manuscript was carried out by R.W. and M.B. All authors have read and agreed to the published version of the manuscript.

Funding: This research was funded by German Academic Exchange Service DAAD, grant number 57504740.

Acknowledgments: This study was conducted in the project 'Sustainable textile supply chains in Ethiopia and Germany' which is funded by the German Academic Exchange Service DAAD.

Conflicts of Interest: The authors declare no conflict of interest. The funders had no role in the design of the study; in the collection, analyses, or interpretation of data; in the writing of the manuscript, or in the decision to publish the results.

\section{Appendix A. Questionnaire}

Short introduction of interview partner

- Name

- Company's name

- Which position do you hold in your company?

- What are your responsibilities within the company? How does your daily work look like?

Presentation of the company

- Since when does the company exist?

- What are the primary business activities and objectives?

- Which products are sold?

- Through which channels are those distributed? (online shop, retail, wholesale?)

- How many stores are there in how many countries?

Managerial orientation toward sustainability

- How would you define sustainability?

- Which importance does sustainability have in relation with the textile industry?

- How important is this topic for your company/in your daily business?

- Is sustainability communicated to the lower management level/operations field? (How?)

- Who is responsible for a sustainable development in your company?

Description of the value chain

- Who are your customers and who is your target group?

- Who are your partners and your suppliers?

- With how many suppliers do you work together?

- Has there already been a transformation towards sustainability of your supply chains or parts of those? If yes, why?

- How does your competitive environment affect your sustainable practices?

- Which role do interest groups play e.g., customers, investors implementing sustainable practices?

- Do you work together with NGOs, competitors, and/or regulators to achieve sustainability along your supply chains?

- Is your company a member of initiatives or alliances regarding sustainability?

Production 
- In which countries are your clothes are produced? How many facilities are involved in the manufacturing process?

- Where are your raw materials from? Which materials are used for your clothes?

- How important is traceability of the products during each step and way of the manufacturing process?

- How does your company control this?

- Are there standards, rules and regulations regarding working conditions and health of workers (child labour, working hours, wages), environment (water, chemicals used, disposal), safety conditions.

- How do you ensure that the facilities and the companies that control these really comply with standards, rules and regulations? Who controls the conditions?

- Are there any approaches to minimize the carbon footprint and the ecological damage of the textile industry from your company?

Transportation

- Do you work together with logistic providers including sustainable aspects?

- Purchasing/Procurement and product design

- Do you think of sustainability aspects by choosing the material?

- Does longevity play an important role? If yes, what are you doing to create this?

- How important is the material selection regarding product life cycle and the recyclability?

- Are your products marked with seals of approval?

Sustainable standards and certificates

- What kind of sustainability-related standards and certificates are used within your supply chain?

- Are there any standards that are only used within your company?

- Network cooperation, communication, coordination and supplier relationship

- How do you select your suppliers? Do you have specific sustainable-related criteria?

- How do you control that your suppliers comply with your criteria?

- Do you use supplier development and audits regarding sustainability?

- Did you define common goals with your suppliers achieving sustainability?

- To what extent can supplier relationships contribute to a sustainable development?

Practice-based view

- Which sustainable-related practices can easily be implemented from other companies within the industry sector and which are company-specific?

- Which material and non-material profit result from implementing sustainable practices in the supply chain?

- What are/were essential success factors and barriers implementing sustainable standards along the supply chain?

- What are the most important prerequisites designing sustainable supply chains?

- Which importance does transparency have regarding the whole supply chain network and how can this be achieved?

Future/Development

- Are there any sustainable-related projects, campaigns or transformations planned? (social, economic, ecological) 


\section{References}

1. Iannone, R.; Martino, G.; Miranda, S.; Riemma, S. Modeling Fashion Retail Supply Chain through Causal Loop Diagram. IFAC-PapersOnLine 2015, 48, 1290-1295. [CrossRef]

2. Bruce, M.; Daly, L.; Towers, N. Lean or Agile: A Solution for Supply Chain Management in the Textiles and Clothing Industry? Int. J. Oper. Prod. Manag. 2004, 24, 151-170. [CrossRef]

3. Dicken, P. Global Shift: Mapping the Changing Contours of the World Economy, 7th ed.; The Guilford Press: New York, NY, USA, 2015.

4. Gold, S.; Awasthi, A. Sustainable Global Supplier Selection Extended Towards Sustainability Risks from $(1+n)$ th Tier Suppliers Using Fuzzy AHP Based Approach. IFAC-PapersOnLine 2015, 43, 111-116. [CrossRef]

5. Kumar, N.; Agrahari, R.P.; Roy, D. Review of Green Supply Chain Processes. IFAC-PapersOnLine 2015, 48, 374-381. [CrossRef]

6. Kobza, N.; Schuster, A. Building a Responsible Europe-The Value of Circular Economy. IFAC-PapersOnLine 2016, 49, 111-116. [CrossRef]

7. Andersen, M.; Skjoett-Larsen, T. Corporate Social Responsibility in Global Supply Chains. Supply Chain Manag. Int. J. 2009, 14, 75-86. [CrossRef]

8. LoMonaco-Benzing, R.; Ha-Brookshire, J. Sustainability as Social Contract: Textile and Apparel Professionals' Value Conflicts within the Corporate Moral Responsibility Spectrum. Sustainability 2016, 8, 1278. [CrossRef]

9. Sauer, C.; Seuring, S. Extending the Reach of Multi-Tier Sustainable Supply Chain Management -Insights from Mineral Supply Chains. Int. J. Prod. Econ. 2018, 217, 31-43. [CrossRef]

10. Seuring, S.; Müller, M. From a Literature Review to a Conceptual Framework for Sustainable Supply Chain. J. Clean. Prod. 2008, 16, 1699-1710. [CrossRef]

11. Yadlapalli, A.; Rahman, S.; Gunasekaran, A. Socially Responsible Governance Mechanisms for Manufacturing Firms in Apparel Supply Chains. Int. J. Prod. Econ. 2018, 196, 135-149. [CrossRef]

12. Winter, S.; Lasch, R. Environmental and Social Criteria in Supplier Evaluation - Lessons from the Fashion and Apparel Industry. J. Clean. Prod. 2016, 139, 175-190. [CrossRef]

13. Elkington, J. Cannibals with Forks: The Triple Bottom Line of 21st Century Business; Capstone Publishing: Oxford, UK, 1997.

14. Brandenburg, M.; Gruchmann, T.; Oelze, N. Sustainable Supply Chain Management-A Conceptual Framework and Future Research Perspectives. Sustainability 2019, 11, 7239. [CrossRef]

15. Brömer, J.; Brandenburg, M.; Gold, S. Transforming Chemical Supply Chains toward SustainabilityA Practice-Based View. J. Clean. Prod. 2019, 236, 117701. [CrossRef]

16. Pagell, M.; Wu, Z. Building a More Complete Theory of Sustainable Supply Chain Management Using Case Studies of 10 Exemplars. J. Supply Chain Manag. 2009, 45, 37-56. [CrossRef]

17. Suchanek, A. Ökonomische Ethik; Mohr Siebeck: Tübingen, Germany, 2001.

18. Seuring, S. Integrated Chain Management and Supply Chain Management Comparative Analysis and Illustrative Cases. J. Clean. Prod. 2004, 12, 1059-1071. [CrossRef]

19. Zhu, Q.; Sarkis, J. An Inter-Sectoral Comparison of Green Supply Chain Management in China: Drivers and Practices. J. Clean. Prod. 2006, 14, 472-486. [CrossRef]

20. Beske, P.; Seuring, S. Putting Sustainability into Supply Chain Management. Supply Chain Manag. Int. J. 2014, 19, 322-331. [CrossRef]

21. Carter, C.R.; Rogers, D.S. A Framework of Sustainable Supply Chain Management: Moving toward New Theory. Int. J. Phys. Distrib. Logist. Manag. 2008, 38, 360-387. [CrossRef]

22. Kot, S.; Haque, A.U.; Kozlovski, E. Strategic SCM's Mediating Effect on the Sustainable Operations: Multinational Perspective. Organizacija 2019, 52, 219-235. [CrossRef]

23. Khurana, K.; Ricchetti, M. Two Decades of Sustainable Supply Chain Management in the Fashion Business, an Appraisal. J. Fash. Mark. Manag. 2016, 20, 89-104. [CrossRef]

24. Muthukumarana, T.T.; Karunathilake, H.P.; Punchihewa, H.K.; Manthilake, M.M.; Hewage, K.N. Life Cycle Environmental Impacts of the Apparel Industry in Sri Lanka: Analysis of the Energy Sources. J. Clean. Prod. 2018, 172, 1346-1357. [CrossRef]

25. Köksal, D.; Strähle, J.; Müller, M.; Freise, M. Social Sustainable Supply Chain Management in the Textile and Apparel Industry-A Literature Review. Sustainability 2017, 9, 100. [CrossRef] 
26. Oelze, N. Implementierung von Umwelt und Sozialstandards entlang der Wertschöpfungskette: Lernen aus Erfahrungen führender Unternehmen. In CSR und Beschaffung; Fröhlich, E., Ed.; Springer Gabler: Berlin/Heidelberg, Germany, 2015; pp. 37-54. [CrossRef]

27. Haseeb, M.; Kot, S.; Hussain, H.I.; Mihardjo, L.W.W.; Saluga, P.W. Modelling the Non-Linear Energy Intensity Effect Based on a Quantile-on-Quantile Approach: The Case of Textiles Manufacturing in Asian Countries. Energies 2020, 13, 2229. [CrossRef]

28. Bottani, E.; Tebaldi, L.; Lazzari, I.; Casella, G. A Model for Assessing Economic and Environmental Sustainability Dimensions of a Fashion Supply Chain and a Case Study. IFAC-PapersOnLine 2019, 52, 261-366. [CrossRef]

29. Fletcher, K.; Grose, L. Fashion and Sustainability: Design for Change; Laurence King Publishing: London, UK, 2012.

30. Warasthe, R.; Brandenburg, M. Sourcing Organic Cotton from African Countries-Potentials and Risks for the Apparel Industry Supply Chain. IFAC-PapersOnLine 2018, 51, 297-301. [CrossRef]

31. Paul, D. Die Textil- und Bekleidungsindustrie der EU: Strukturen, Strategien, Perspektiven; Igel Verlag: Hamburg, Germany, 2008.

32. Freise, M.; Seuring, S. Social and Environmental Risk Management in Supply Chains. Logist. Res. $2015,8,2$. [CrossRef]

33. Nash International, BV. Business Opportunity Report Ethiopia- Textile E Apparel Industry; Nash International BV: Rotterdam, The Netherlands, 2019; Available online: https://www.academia.edu/29355486/ BUSINESS_OPPORTUNITY_REPORT_ETHIOPIA_TEXTILE_and_APPAREL_INDUSTRY (accessed on 20 September 2020).

34. American Bar Association Rule of Law Initiative. Case Study: Ethiopian Textile Industry; American Bar Association Rule of Law Initiative, 2017. Available online: https://www.verite.org/wp-content/uploads/2017/ 12/ABA-ROLI-Case-Study-Ethiopia-Aug-2017.pdf (accessed on 3 September 2020).

35. Khurana, K. An Overview of Textile and Apparel Business Advances in Ethiopia. Res. J. Text. Appar. 2018, 22, 212-223. [CrossRef]

36. Mukendi, A.; Davies, I.; Glozer, S.; McDonagh, P. Sustainable Fashion: Current and Future Research Directions. Eur. J. Mark. 2020. [CrossRef]

37. Kunz, J.; May, S.; Schmidt, H.J. Sustainable Luxury: Current Status and Perspectives for Future Research. Bus. Res. 2020, 13, 541-601. [CrossRef]

38. Yang, S.; Song, Y.; Tong, S. Sustainable Retailing in the Fashion Industry: A Systematic Literature Review. Sustainability 2017, 9, 1266. [CrossRef]

39. Garcia-Torres, S.; Albareda, L.; Rey-Garcia, M.; Seuring, S. Traceability for Sustainability-Literature Review and Conceptual Framework. Supply Chain Manag. Int. J. 2019, 24, 85-106. [CrossRef]

40. Sirilertsuwan, P.; Ekwall, D.; Hjelmgren, D. Proximity Manufacturing for Enhancing Clothing Supply Chain Sustainability. Int. J. Logist. Manag. 2018, 29, 1346-1378. [CrossRef]

41. Karaosman, H.; Morales-Alonso, G.; Brun, A. From a Systematic Literature Review to a Classification Framework: Sustainability Integration in Fashion Operations. Sustainability 2017, 9, 30. [CrossRef]

42. Jia, F.; Yin, S.; Chen, L.; Chen, X. Circular Economy in Textile and Apparel Industry: A Systematic Literature Review. J. Clean. Prod. 2020, 259, 120728. [CrossRef]

43. Stuart, I.; McCutcheon, D.; Handfield, R.; McLachlin, R. Effective Case Research in Operations Management: A Process Perspective. J. Oper. Manag. 2002, 20, 419-433. [CrossRef]

44. Bryman, A.; Bell, E. Business Research Methods, 5th ed.; Oxford University Press: New York, NY, USA, 2019.

45. Yin, R.K. Case Study Research and Applications: Design and Methods, 6th ed.; Sage Publishing: Los Angeles, CA, USA, 2018.

46. Kuckartz, U.; Dresing, T.; Rädiker, S.; Stefer, C. Qualitative Evaluation: Der Einstieg in die Praxis, 1st ed.; VS Verlag für Sozialwissenschaften: Wiesbaden, Germany, 2007. [CrossRef]

47. Mayring, P. Qualitative Content Analysis: Theoretical Foundation, Basic Procedures and Software Solution; Beltz: Klagenfurt, Austria, 2014.

48. Seuring, S.; Müller, M.; Westhaus, M.; Morana, R. Conducting a Literature Review-The Example of Sustainability in Supply Chains. In Research Methodologies in Supply Chain Management; Kotzab, H., Seuring, S., Müller, M., Reiner, G., Eds.; Physica-Verlag: Heidelberg, Germany, 2005; pp. 91-106. [CrossRef] 
49. Oelze, N.; Gruchmann, T.; Brandenburg, M. Motivating Factors for Implementing Apparel Certification Schemes-A Sustainable Supply Chain Management Perspective. Sustainability 2020, 12, 4823. [CrossRef]

50. Berg, A.; Hedrich, S. East Africa: The Next Hub for Apparel Sourcing; McKinsey and Company-Retail Practice: Frankfurt, Germany, 2015; Available online: https://www.mckinsey.com/industries/retail/our-insights/eastafrica-the-next-hub-for-apparel-sourcing (accessed on 23 September 2020).

51. Oelze, N. Sustainable Supply Chain Management Implementation-Enablers and Barriers in the Textile Industry. Sustainability 2017, 9, 1435. [CrossRef]

52. Raut, R.; Gardas, B.B.; Narkhede, B. Ranking the Barriers of Sustainable Textile and Apparel Supply Chains. Benchmarking Int. J. 2019, 26, 371-394. [CrossRef]

53. Chowdhury, M.M.H.; Umme, N.J.; Nuruzzaman, M. Strategies for Mitigating Supply-Side Barriers in the Apparel Supply Chain: A Study on the Apparel Industry of Bangladesh. Glob. J. Flex. Syst. Manag. 2018, 19, 41-52. [CrossRef]

54. Zhu, Q.; Sarkis, J.; Geng, Y. Barriers to Environmentally-Friendly Clothing Production among Chinese Apparel Companies. Asian Bus. Manag. 2011, 10, 425-452. [CrossRef]

55. Rundassa, M.W.; Azene, D.K.; Berhan, E. Comparative Advantage of Ethiopian Textile and Apparel Industry. Res. J. Text. Appar. 2019, 23, 244-256. [CrossRef]

56. Wakeford, J.J.; Gebreeyesus, M.; Ginbo, T.; Yimer, K.; Manzambi, O.; Okereke, C.; Black, M.; Mulugetta, Y. Innovation for Green Industrialisation: An Empirical Assessment of Innovation in Ethiopia's Cement, Leather and Textile Sectors. J. Clean. Prod. 2017, 166, 503-511. [CrossRef]

57. Georgise, F.B.; Thoben, K.-D.; Seifert, M. Application of the Adapted SCOR Model to the Leather Industry: An Ethiopian Case Study. In Dynamics in Logistics, Lecture Notes in Logistics; Kotzab, H., Pannek, J., Thoben, K.-D., Eds.; Springer: Heidelberg, Germany, 2016; pp. 441-451. [CrossRef]

58. Prasad, S.; Jaffe, J.; Bhattacharyya, K.; Tata, J.; Marshall, D. Value Supply Chains at the Base of the Pyramid: Studies of Past and Present Textile Networks. J. Humanit. Logist. Supply Chain Manag. 2017, 7, 304-323. [CrossRef]

Publisher's Note: MDPI stays neutral with regard to jurisdictional claims in published maps and institutional affiliations.

(C) 2020 by the authors. Licensee MDPI, Basel, Switzerland. This article is an open access article distributed under the terms and conditions of the Creative Commons Attribution (CC BY) license (http://creativecommons.org/licenses/by/4.0/). 